\title{
VILLANÓFÉNYBEN AZ ÁRNYÉKOKTATÁS
}

\author{
LEHOTKA ILDIKÓ \\ Debreceni Egyetem, Nevelés- és Művelődéstudományi Doktori Iskola
}

Young Chun Kim \& Jung-Hoon Jung: Shadow Education as Worldwide Curriculum Studies. (Curriculum Studies Worldwide series.) Cham, 2019. Palgrave Macmillan. $\mathrm{xi}+212$ p. ISBN 978-3-030-03982-0 (eBook)

Mióta szervezett formában történik az oktatás, azóta van igény arra is, hogy a színvonalát emeljék. Ennek egyik lehetséges módja a tanórákon kívüli képzés, $\mathrm{a} z$ árnyékoktatás. $\mathrm{Az}$ árnyékoktatásról olykor még szépirodalmi művekben is szó esik, például Charlotte Brontë Jane Eyre címü könyvében, vagy magyar példaként említhetjük Móricz Zsigmond Légy jó mindhaláligját, ahol Nyilas Misi korrepetálja latinból és matematikából Doroghy Sanyikát, havi két pengőért.

$\mathrm{A} z$ árnyékoktatás mára a formális tanulást kiegészítő, azt segítő ágazattá vált, világszerte terjed, egyre nagyobb az igény iránta. A kötelező, szervezett oktatás mellett valószínúleg mindig lesz kereslet különórákra - fizetett formában vagy ingyenesen, iskolák által szervezett szakkörök formájában. Az 1990-es évektől a kiegészítő magánoktatás (pl. cram school néven) már közoktatási dokumentumokban is megjelenik.

Az árnyékoktatás 1999 óta általánosan használatos kifejezés: nemcsak oktatás, hanem egyéb, oktatási célt szolgáló tevékenységek is idesorolandók. Az árnyékoktatást igénybe vevő tanulók segítséget kapnak már megoldott vagy még nem megoldott feladatokhoz, előadásokat követhetnek CD-lemezröl vagy az interneten keresztül, útmutatókat vagy megjegyzéseket kapnak papír alapon vagy online.

Magyarországon az árnyékoktatás jelenthet extrakurrikuláris tevékenységeket, illetve iskolai kereteken túlmutató foglalkozásokat. Az iskolai órarend nem foglalja magában a szakköröket, a felzárkóztató foglalkozásokat, a nem ének-zene tagozatos iskolák énekkari foglalkozásait, a rajz- és más tárgyakból tartott pluszórákat és egyéb ingyenes tanulási alkalmakat. A tantervi órákon kívül a tanulók részt vehetnek fizetős foglalkozásokon is az iskolákban, például sportfoglalkozásokon, néptáncoktatáson, középiskolai felvételire vagy érettségi vizsgára történő előkészítőn. Olyan pluszórák is elérhetők számukra, amelyeket nem a saját iskolájukban tartanak, például a már említett néptáncoktatás vagy a középiskolai felvételi előkészítő.

A tanulók olyan órákat is látogathatnak, amelyeket nem az iskola szervez, hanem magántanárok vagy magánoktatásra szakosodott cégek kínálnak. Magántanár- 
hoz leggyakrabban matematikakorrepetálás és nyelvtanulás céljából fordulnak a szülők, az árnyékoktatásra szakosodott cégek a nyelvtanításra összpontosítanak, illetve egyfajta globális (felzárkóztató) képzést nyújtanak. Idetartoznak a sportolási lehetőséget kínáló klubok, a balettórákat szervező cégek, az állami és magánfenntartású zeneiskolák is.

A dél-koreai szerzők, Young Chun Kim és Jung-Hoon Jung kötete kilenc fejezetben mutatja be az árnyékoktatás fontosságát, annak lehetséges színtereit - kitérve még arra is, hogy az iskolai oktatáson túlmutató "globális tanulási láz" vajon az árnyékoktatáshoz sorolható-e. A szerzők fogalomtisztázással vezetik be tanulmánykötetüket, a tanterv jelentését vizsgálják számos szemszögből. Az oktatási folyamat alapjául szolgáló tanterv fogalma sokat változott azóta, hogy a gyermekek szervezett oktatásban részesülnek. Ahogy a tanterv gazdagodott az évszázadok folyamán, úgy változott, pontosodott a jelentése is. A tanterv fogalmának korszerü leírása már tartalmazza többek között a társadalmi-politikai változást, fejlődést, a genderelmélet koncepcióját, történelmi, kulturális elemeket, vagy az adott ország vallási környezetét. A 21. századi definíciók nagy része a játékos tanulás szükségességét is jelzi.

A tanterv magában hordozza a rejtett tantervet (implicit tanterv vagy hidden curriculum) is, amely a nem tantárgyi formában átadott ismeret, mégis fontos tényező a tanítás folyamatában (például a viselkedés, kulturális szokások). A szakirodalomban új fogalomként megjelent az árnyéktanmenet, amely a tanulók iskolán kívüli tanulásának folyamatára fókuszál.

A szerzők fontosnak tartják megjegyezni, hogy az árnyékoktatás révén a tanulók nemcsak ismereteiket gyarapíthatják, de tanulási kultúrájukat is fejleszt- hetik. Emiatt a tantervi kutatás sem korlátozódhat magukra a tantervekre, vizsgálni kell a kiegészítő oktatási jelenségeket, az árnyékoktatás hatásait, lehetőségeit is. Sőt, a „kiegészítő” jelző ma már valószínüleg idejétmúlt, hiszen az árnyékoktatás a globális képzés egyik fontos formája.

$\mathrm{A} z$ árnyékoktatás jellemzőit is többféle szempontból vizsgálják a szerzők. Tömören és összefoglalóan megállapíthatjuk, hogy az árnyékoktatáshoz sorolják azokat a tevékenységeket, amelyek révén a tanulók az iskolai tanórákon tanultakat elmélyíthetik, illetve azt a segítséget, amelyet magántanárok, árnyékoktatásra szakosodott intézmények ehhez nyújtanak. Az árnyékoktatás részletes meghatározását és több szempontú elemző vizsgálatát a kötet hetedik fejezete ismerteti.

$\mathrm{A} z$ árnyékoktatás a kelet-ázsiai országokban (Dél-Koreában, Japánban, Hongkongban, Tajvanon, Szingapúrban) a legelterjedtebb. Hozzájuk képest például jóval kevésbé nő az árnyékoktatásban részt vevők aránya az Amerikai Egyesült Államokban. Kiemelt jelentőségű az árnyékoktatás Dél-Koreában (a tanulók körülbelül $70 \%$-át érinti). Dél-Koreában bakwon az elnevezése azoknak az intézményeknek, amelyekben az állami oktatás mellett tanulhatnak a gyermekek. Ezeknek nyolc típusa van, amelyekben különböző tantárgyak tanulását fejlesztik, vagy általános segítséget nyújtanak a következőkben: matematika, íráskészség, átfogó képzés, speciális oktatás középiskolásoknak, tehetségoktatás, internetalapú képzés, sőt, a bentlakásos iskolák is a kínálathoz tartoznak.

Japánban az árnyékoktatás neve juku (felvételire és vizsgákra készíti fel a tanulókat), Tajvanon buxiban (itt különféle tantárgyak oktatása folyik) vagy anchinban (ez a magyar napközinek megfelelő feladatokat lát el), Indonéziában abimbel vagy bimbingan, Kínában pedig sishu. 
$\mathrm{A} z$ ármyékoktatás természetesen Európában és Afrikában is jelen van, de előbbivel a könyv csak keveset foglalkozik, utóbbi pedig mindössze egy-egy alfejezet néhány mondatában szerepel. Európában egyébként az árnyékoktatás gyakoribb a déli, közép- és kelet-európai országokban (beleértve Görögországot, Lengyelországot, Lettországot és Spanyolországot), a legkevésbé elterjedt a nyugati és északeurópai régióban - különösen Dániában, Svédországban és Finnországban. NagyBritanniában a Londonban tanulók jutnak nagyobb eséllyel árnyékképzéshez, mivel itt találhatóak a leggazdagabb választókerületek, ahol a szülők meg tudják fizetni a magas díjat, emellett és emiatt sok a magántanulást segítő ügynökség, és nem utolsósorban magas a független iskolák száma.

A szerzők könyvükben arra is keresik a választ, hogy miért a kelet-ázsiai országok, illetve a más országokban élő kelet-ázsiaiak teljesítettek a legjobban az utóbbi három PISA-teszten. Szerintük ez többek közt a konfuciánus hagyománnyal magyarázható, valamint azzal, hogy egyes szülők (az USA kínai közösségeiben a „tigris anyák”, Dél-Koreában a „gangnam anyák") szinte erőn felül mindent megtesznek azért, hogy gyermekük számára a legjobb oktatást, iskolát, tanárt biztosítsák. A tanulók egy héten többször is kapnak képzést az iskolai órák után, nem egy esetben késő estig vannak a foglalkozások.

A szerzők az árnyékoktatást színterei alapján négy kategóriára osztották. Az első és leggyakoribb a magántanár (privat tutor) intézménye. A magántanárok általában a diák otthonában tartják meg a foglalkozást, esetenként két-három tanulóval is foglalkoznak. A díjazásuk képzettségüktől és az oktatott tanuló iskolai szintjétől függ. $\mathrm{Az}$ Amerikai Egyesült Államokban a tehetősebb családok nemritkán „házitanítót” fogadnak gyermekeik mellé, a megbízás ott lakással, autóhasználattal, étkezéssel, esetenként nyaralással jár együtt.

A második kategóriába sorolták a szerzők az intézményesített árnyékoktatást. A csoportos órák tanteremben vagy tanteremszerű helyiségben folynak. Idetartozik a balettoktatás, egyéb csoportos, müvészeti oktatás. A foglalkozásokat hetente többször, a nyári szünet alatt is megtartják.

A harmadik kategória az előfizetéses oktatás - a tanulni vágyók postai úton kapják meg a feladatokat (az 1950-es évektől létezik ilyen hálózat Japánban, eleinte kumon, majd baksupji néven). A legtöbb cég hetente egyszer tanárokat is küld a tanulókhoz, hogy megválaszolják a felmerülő kérdéseket, segítsenek megoldani a feladatokat.

A negyedik kategóriába végül a tanítás utáni változatos programok szervezése és lebonyolítása tartozik. Ez a fajta árnyékoktatás gyakran áll kormányzati szabályozás alatt, a foglalkozásokra a tanuló megszokott napközbeni környezetében kerítenek sort. A tanítás utáni programok nem a tanulást segítő célokra fókuszálnak, hanem a nívós szabadidő-eltöltésre, és gyakran a gyermekfelügyeletet is magukban foglalják.

$\mathrm{Az}$ árnyékoktatás pozitív vonása a szerzők és a hivatkozott tanulmányok szerint az, hogy személyre szabottan, informális keretek között működik, a tanulók kérdezhetnek a foglalkozásvezetőtől (a formális oktatás keretein belül erre nem mindig adódik alkalom, gyakran a tanulók nem is mernek kérdezni a tanártól). Pozitív, ösztönző kapcsolat alakulhat ki a tanár és a tanuló között, így a tanulás minősége is javulhat. A tanulók a magasabb, korszerúbb tudás megszerzése, a tanulási technikák javítása, a tesztírási rutinszerzés, a felvételi vizsgák remélhető sikere érdekében látogatják ezeket a nem kötelező órákat. 
$\mathrm{A} z$ árnyékoktatásban részt vevők több időt fordítanak a tanulásra, ezért a felvételi vizsgákon, a tesztek megírásában is eredményesebbek.

$\mathrm{A} z$ árnyékoktatás azonban nem mindenki számára megfizethető, így fokozza az oktatási egyenlőtlenségeket. (Ezt részben úgy lehet ellensúlyozni, hogy kiválasztják azokat a szegényebb tanulókat, akik kiemelkednek az átlagból, és a képzésüket átvállalja az állam vagy egy alapítvány.) $\mathrm{Az}$ árnyékoktatás másik negatív vonása a szerzők szerint az, hogy a pluszórákon való részvétel sok tanuló számára kimerítő, és az elvárt fejlődés sem mindig biztosított. Van olyan kutató, aki egyenesen úgy fogalmaz, hogy az árnyékoktatás a gyermekbántalmazás egy formája.

A kötet ötödik fejezete az árnyékképzésben megvalósuló matematikaoktatást szemlélteti. Nemcsak hazánkban, hanem másutt is a matematika az oktatás és a tanulás neuralgikus pontja. Mivel emellett általában felvételi tárgy is a középiskolai, felsőoktatási felvételi eljárásban, nem véletlen, hogy a matematika iránt van a legnagyobb kereslet az árnyékoktatásban. A hatodik fejezet a tehetséges, illetve a magasan motivált dél-koreai tanulók lehetőségeit, illetve a hakwon és a youngjae osztályok árnyéktantervét mutatja be. A kötet az államilag szervezett oktatás utáni kép- zési lehetőségeket is sorra veszi egy teljes fejezeten keresztül.

Amíg a kelet-ázsiai országokban, Európa egyes részein vagy az Amerikai Egyesült Államokban és Kanadában létrejött árnyékoktatást végző intézmények komoly gazdasági hasznot hoznak, addig Magyarországon a formális oktatáson kívüli felzárkóztató foglalkozást, nyelvórát, egyéb órát tartó tanárok nagy része még csak nem is adózik a tevékenysége után. Nálunk egyelőre az árnyékoktatás fajtái közül leginkább a magántanári, illetve az internetalapú, pl. skype közvetítésével végzett oktatásra van kereslet. Árnyékoktatásra szakosodott intézményből, tanodából egyelöre meglehetősen kevés van. Itthon a felzárkóztatás, a leckeíráshoz nyújtott segítség, a nyelvvizsgára készülés a fö oka annak, hogy tanárhoz fordul a szülő, kevésbé az új ismeretek megszerzése a cél.

A két szerző kötete mindenképpen elgondolkodtató. Az árnyékoktatás hasznát több oldalról világítják meg, néha egy-egy tény, gondolatmenet több helyen is felbukkan a könyvben. Számos ország árnyékoktatási gyakorlatáról olvashatunk, talán érdemes lett volna néhány példával a volt szocialista régiót vagy az afrikai fejlődő országok egyikét-másikát is szerepeltetni, esetleg összehasonlítani a kelet-ázsiai gyakorlattal.

A cikk a Creative Commons Attribution 4.0 International License (https://creativecommons.org/licenses/ by-nc/4.0/) feltételei szerint publikált Open Access közlemény, melynek szellemében a cikk bármilyen médiumban szabadon felhasználható, megosztható és újraközölhető, feltéve, hogy az eredeti szerző és a közlés helye, illetve a CC License linkje és az esetlegesen végrehajtott módosítások feltüntetésre kerülnek. 